\title{
Erratum: Geochronology of Late Cenozoic Volcanism in the Area of Lake Van, Turkey: An Example of Developmental Dynamics for Magmatic Processes [Doklady Earth Sciences, 433(2), pp. 1031-1037]
}

\author{
V. A. Lebedev ${ }^{a}$, E. V. Sharkov ${ }^{a}$, M. Keskin ${ }^{b}$, and V. Oyan ${ }^{c}$ \\ Presented by Academician V.I. Kovalenko December 10, 2009
}

Received December 30, 2009

\begin{abstract}
An isotope-geochronological study has been performed to examine the products of Late Cenozoic collision volcanism on the northern coast of Lake Van, Turkey. We obtained 45 new K-Ar dates, based on which the principal time characteristics of volcanic activity in the region have been determined. Volcanic activity in the northern coast of Lake Van has lasted $\sim 15$ myr; it has had an expressed discrete nature, when periods of intense volcanic activity alternated with long-lasting pose periods. Four stages of Neogene-Quaternary volcanism have been identified: Middle Miocene (15.0-13.5 Ma), Late Miocene (10-9 Ma), Pliocene (5.8-3.7 Ma), and Quaternary (1.0-0.4 Ma). The average duration of the stages was 1-2 myr; the stages were separated from each other with periods of inactivity of approximately equal lengths $(\sim 3 \mathrm{myr})$. For each of the Pliocene and Quaternary stages, three additional phases of volcanism have been identified, which were separated from each other with short time intervals (a few hundred thousand years). The last burst of volcanic activity in the study area occurred $\sim 400 \mathrm{ka}$; similar to Quaternary volcanism in general, it was not characterized by a high intensity. An important result of the studies performed was to confirm the existence of a separate Middle Miocene stage of collision volcanism for the Caucasian-Anatolian Segment of the Alpine Fold Belt. New geochronological data generated presented in this paper indicate that Neogene-Quaternary volcanism in this portion of the belt started much earlier ( $\sim 15 \mathrm{Ma})$ than assumed by the majority of the previous researchers.
\end{abstract}

DOI: $10.1134 / \mathrm{S} 1028334 \mathrm{X} 10110309$

The Caucasian-Anatolian Segment of the Alpine Fold Belt that comprises the mountain structures of the Greater and Lesser Caucasus and the Eastern Anatolian Highland belongs to those regions of the Earth where collision magmatism became widespread during the Neogene-Quaternary period. This magmatism manifests itself there in complex geotectonic conditions of intense convergence of the Eurasian, Arabian, Turkish, and Iranian lithosphere plates and a number of microterrains [1, etc.]. One of the largest areas of young volcanism in Eastern Anatolia, Turkey, is the Northern Van neovolcanic province [2]; it is located on the northern coast of Lake Van and covers $\sim 6000 \mathrm{~km}^{2}$. The products of Neogene-Quaternary

a Institute of Geology of Ore Deposits, Petrography, Mineralogy, and Geochemistry, Russian Academy of Sciences, Staromonetnyi per. 35, Moscow, 119017 Russia

${ }^{b}$ Istanbul University, Faculty of Engineering, Dept. of Geological Engineering, 34320 Avcilar, Istanbul, Turkey

${ }^{c}$ Van Yüzüncü Yil University, Faculty of Architecture and Engineering, Dept. of Geological Engineering, Zeve Campus, Van, Turkey magmatic activity in the region, formed at different stages of young volcanism of the Eastern Anatolian Highland, have a wide compositional range from alkaline basalts to rhyolites and trachyrhyolites. A comprehensive study of the evolution of Late Cenozoic volcanic activity in this region will undoubtedly play an important role in understanding the reasons for and the regularities of the development of collision magmatism within the Caucasian-Anatolian Segment as a whole.

This paper discusses the results of an isotope-geochronological study of collision-related young volcanic rocks of the southeastern part of the Northern Van region that covers the area located on the northern coast of Lake Van between the town of Ercis in the west and the valley of the Bendimahi River in the east (see figure). The basement of the study area is represented by three different units: an ophiolitic mélange which is Cretaceous-Paleogene in age, metamorphic units which are Paleozoic in age and granitoids which are thought to be Mesozoic in age. The last two basement units compose the Aladag Massif. The exposures of ophiolitic mélange are observed everywhere beneath the Aladag Massif in the north. The ophio- 


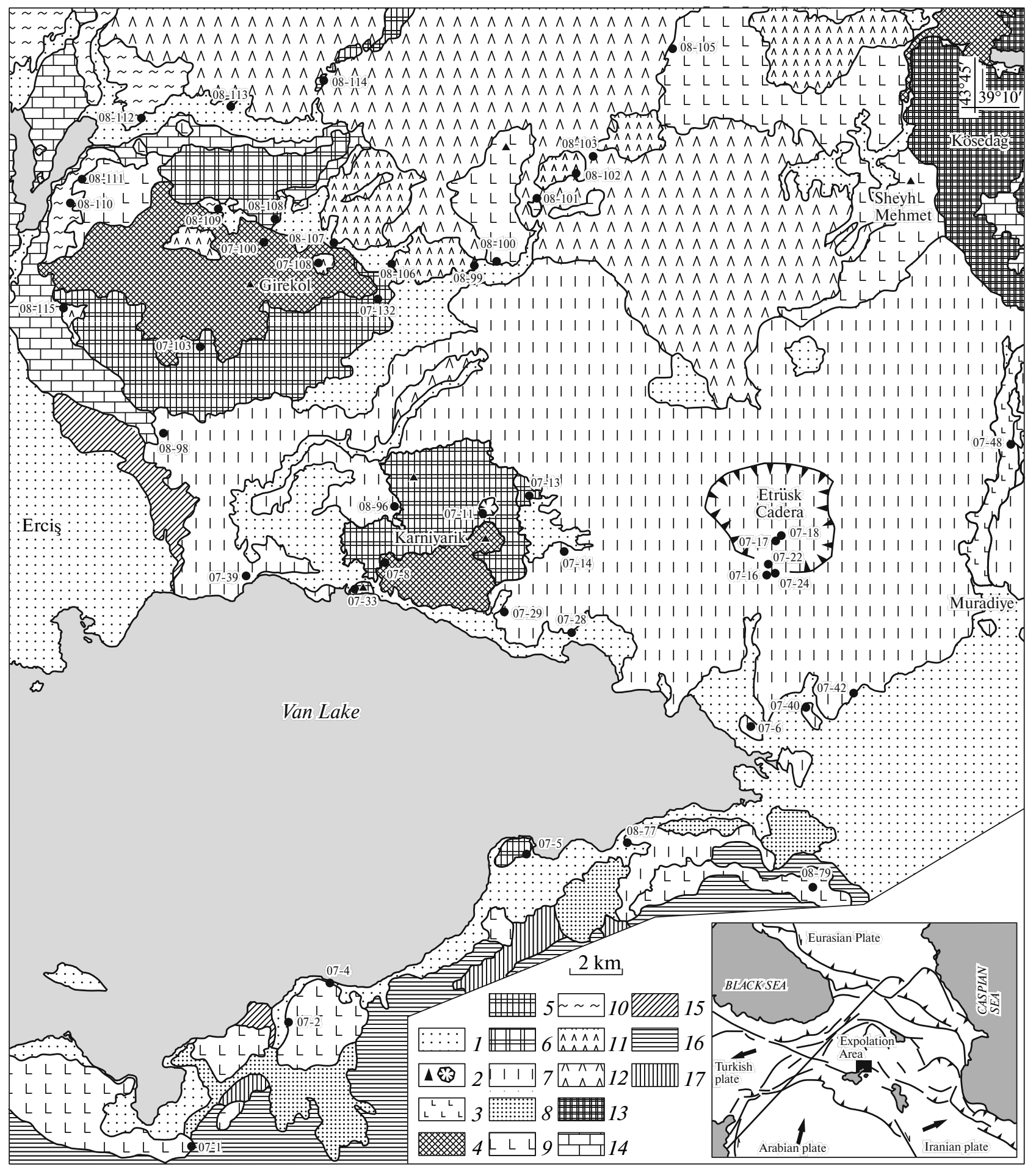

Geological map of the northern coast of Lake Van (prepared by V.A. Lebedev). 1, Quaternary sediments; 2, volcanoes and craters; 3, Quaternary alkali basalts of the Tendürek Volcano; 4, Quaternary basalts and trachybasalts (phase 3); 5, Quaternary basalts and basaltic trachyandesites (phase 2); 6, Quaternary basalts (phase 1); 7, Early Pliocene trachydacites, trachytes, trachyandesites, and rhyolites of the Etrüsk Volcano; 8, pyroclastic rocks of the Etrüsk Volcano (Early Pliocene); 9, Early Pliocene basalts and trachybasalts; 10, Late Miocene basaltic trachyte ignimbrites and pyroclastic rocks; 11, Late Miocene dacites, basalts, and trachybasalts (the second rock sequence of the Aladag Volcanic Complex); 12, Middle Miocene andesites and pyroclastic rocks (the first rock sequence of the Aladag Volcanic Complex); 13, lavas and pyroclastic rocks of the Kösedag Volcano; 14, Pliocene sediments; 15, Miocene sediments; 16, Paleogene-Early Miogene sediments; 17, Triassic sediments. The sample locations are shown in the map. 
Results of K-Ar dating of young volcanic rocks on the northern coast of Van Lake

\begin{tabular}{|c|c|c|c|c|c|}
\hline Sample & $\begin{array}{l}\text { Sample location } \\
(\mathrm{N}, \mathrm{E})\end{array}$ & Rock & $\begin{array}{l}\mathrm{K}(\%) \\
\pm \sigma\end{array}$ & $\begin{array}{c}{ }^{40} \mathrm{Ar}_{\mathrm{rad}}(\mathrm{ng} / \mathrm{g}) \\
\pm \sigma\end{array}$ & $\begin{array}{l}\text { Age (Ma) } \\
\pm 2 \sigma\end{array}$ \\
\hline \multicolumn{6}{|c|}{ Alada Rock Complex, the first rock mass (Middle Miocene) } \\
\hline 08-101 & $39.134420,43.551450$ & \multirow[t]{3}{*}{ Andesite } & $2.12 \pm 0.03$ & $2.126 \pm 0.008$ & $14.4 \pm 0.4$ \\
\hline 08-103 & $39.148700,43.576740$ & & $2.51 \pm 0.03$ & $2.334 \pm 0.008$ & $13.4 \pm 0.3$ \\
\hline $08-113$ & $39.165607,43.418215$ & & $1.94 \pm 0.02$ & $2.009 \pm 0.008$ & $14.9 \pm 0.3$ \\
\hline \multicolumn{6}{|c|}{ Alada Rock Complex, the second rock mass (Late Miocene) } \\
\hline 07-108 & $39.111150,43.456820$ & \multirow[t]{2}{*}{ Dacite } & $2.32 \pm 0.03$ & $1.577 \pm 0.009$ & $9.8 \pm 0.3$ \\
\hline 08-99 & $39.110390,43.524530$ & & $2.32 \pm 0.03$ & $1.522 \pm 0.006$ & $9.4 \pm 0.3$ \\
\hline 08-102 & $39.143230,43.569010$ & Basalt & $0.94 \pm 0.015$ & $0.644 \pm 0.004$ & $9.9 \pm 0.3$ \\
\hline 08-106 & $39.111577,43.488593$ & Dacite & $2.61 \pm 0.03$ & $1.639 \pm 0.006$ & $9.0 \pm 0.2$ \\
\hline 08-107 & $39.118477,43.462854$ & Trachybasalt & $1.38 \pm 0.02$ & $0.941 \pm 0.004$ & $9.8 \pm 0.3$ \\
\hline $08-115$ & $39.095819,43.345665$ & Dacite & $2.58 \pm 0.03$ & $1.595 \pm 0.006$ & $8.9 \pm 0.2$ \\
\hline \multicolumn{6}{|c|}{ Late Miocene ignimbrites and pyroclastic rocks } \\
\hline 08-109 & $39.130160,43.412960$ & Trachyandesite tuff & $1.92 \pm 0.02$ & $0.766 \pm 0.007$ & $5.74 \pm 0.16$ \\
\hline $08-110$ & $39.130709,43.350626$ & Trachyte ignimbrite & $3.56 \pm 0.04$ & $1.366 \pm 0.005$ & $5.52 \pm 0.13$ \\
\hline $08-112$ & $39.160778,43.378646$ & “ & $3.52 \pm 0.04$ & $1.288 \pm 0.007$ & $5.27 \pm 0.13$ \\
\hline \multicolumn{6}{|c|}{ Early Pliocene plateau basalts } \\
\hline $07-1$ & $38.811070,43.402190$ & Basalt & $0.55 \pm 0.015$ & $0.179 \pm 0.004$ & $4.65 \pm 0.30$ \\
\hline $07-2$ & $38.853260,43.444420$ & “ & $0.53 \pm 0.015$ & $0.172 \pm 0.003$ & $4.70 \pm 0.30$ \\
\hline $07-4$ & $38.866060,43.465110$ & “ & $0.50 \pm 0.015$ & $0.170 \pm 0.004$ & $4.90 \pm 0.35$ \\
\hline 08-79 & $38.900490,43.671980$ & “ & $0.42 \pm 0.015$ & $0.132 \pm 0.003$ & $4.50 \pm 0.40$ \\
\hline 08-100 & $39.111600,43.534560$ & “ & $0.68 \pm 0.015$ & $0.230 \pm 0.003$ & $4.90 \pm 0.25$ \\
\hline 08-105 & $39.185680,43.611130$ & Trachybasalt & $1.06 \pm 0.02$ & $0.340 \pm 0.005$ & $4.60 \pm 0.20$ \\
\hline $08-111$ & $39.139230,43.349800$ & “ & $0.94 \pm 0.015$ & $0.319 \pm 0.002$ & $4.90 \pm 0.20$ \\
\hline \multicolumn{6}{|c|}{ Etrusk Volcano (Early Pliocene) } \\
\hline $07-6$ & $38.954010,43.646690$ & Trachyte & $3.95 \pm 0.04$ & $1.169 \pm 0.008$ & $4.26 \pm 0.11$ \\
\hline 07-14 & $39.013140,43.564710$ & “ & $3.08 \pm 0.04$ & $0.902 \pm 0.006$ & $4.22 \pm 0.12$ \\
\hline 07-16 & $39.005310,43.655350$ & Trachydacite & $3.68 \pm 0.04$ & $1.019 \pm 0.09$ & $3.99 \pm 0.11$ \\
\hline $07-17$ & $39.017020,43.658500$ & “ & $2.72 \pm 0.03$ & $0.788 \pm 0.007$ & $4.17 \pm 0.12$ \\
\hline 07-18 & $39.019070,43.659710$ & Trachyandesite & $2.63 \pm 0.03$ & $0.769 \pm 0.009$ & $4.21 \pm 0.13$ \\
\hline $07-22$ & $39.008926,43.655137$ & Trachyte & $3.15 \pm 0.04$ & $0.944 \pm 0.009$ & $4.30 \pm 0.14$ \\
\hline $07-24$ & $39.006960,43.656660$ & “ & $3.40 \pm 0.04$ & $0.928 \pm 0.007$ & $3.93 \pm 0.11$ \\
\hline $07-28$ & $38.985950,43.567970$ & “ & $4.40 \pm 0.05$ & $1.267 \pm 0.007$ & $4.15 \pm 0.11$ \\
\hline 07-29 & $38.993760,43.538510$ & “ & $4.42 \pm 0.05$ & $1.293 \pm 0.010$ & $4.21 \pm 0.11$ \\
\hline $07-39$ & $39.004900,43.427230$ & “ & $3.81 \pm 0.04$ & $1.139 \pm 0.006$ & $4.30 \pm 0.10$ \\
\hline $08-96$ & $39.028929,43.492142$ & Trachyandesite & $2.76 \pm 0.03$ & $0.770 \pm 0.005$ & $4.02 \pm 0.10$ \\
\hline 08-98 & $39.053000,43.388440$ & Trachyte & $3.76 \pm 0.04$ & $1.004 \pm 0.007$ & $3.85 \pm 0.10$ \\
\hline $08-77$ & $38.915860,43.591550$ & Trachyte & $3.92 \pm 0.04$ & $1.036 \pm 0.004$ & $3.81 \pm 0.08$ \\
\hline $07-40$ & $38.960050,43.669080$ & Rhyolite & $4.07 \pm 0.05$ & $1.046 \pm 0.009$ & $3.70 \pm 0.11$ \\
\hline 07-42 & $38.966070,43.693350$ & “ & $4.31 \pm 0.05$ & $1.126 \pm 0.006$ & $3.76 \pm 0.10$ \\
\hline
\end{tabular}


Table. (Contd.)

\begin{tabular}{|c|c|c|c|c|c|}
\hline Sample & $\begin{array}{l}\text { Sample location } \\
\text { (N, E) }\end{array}$ & Rock & $\begin{array}{l}K(\%) \\
\pm \sigma\end{array}$ & $\begin{array}{c}{ }^{40} \mathrm{Ar}_{\mathrm{rad}}(\mathrm{ng} / \mathrm{g}) \\
\pm \sigma\end{array}$ & $\begin{array}{c}\text { Age (Ma) } \\
\pm 2 \sigma\end{array}$ \\
\hline \multicolumn{6}{|c|}{ Quaternary basalts (Girekol, Karnıyarık, and other volcanoes) } \\
\hline $07-13$ & $39.032260,43.549270$ & Basalt & $0.61 \pm 0.015$ & $0.041 \pm 0.003$ & $0.96 \pm 0.12$ \\
\hline 08-108 & $39.126760,43.438170$ & “ & $0.48 \pm 0.015$ & $0.035 \pm 0.003$ & $1.05 \pm 0.19$ \\
\hline $08-114$ & $39.172767,43.458725$ & Basaltic trachyandesite & $1.86 \pm 0.02$ & $0.078 \pm 0.002$ & $0.60 \pm 0.04$ \\
\hline $07-5$ & $38.911040,43.548800$ & Basalt & $0.55 \pm 0.015$ & $0.022 \pm 0.002$ & $0.57 \pm 0.12$ \\
\hline $07-103$ & $39.083120,43.404770$ & “ & $0.56 \pm 0.015$ & $0.023 \pm 0.002$ & $0.60 \pm 0.12$ \\
\hline $07-132$ & $39.099540,43.481710$ & “ & $0.45 \pm 0.015$ & $0.017 \pm 0.003$ & $0.53 \pm 0.15$ \\
\hline 07-11 & $39.026000,43.529050$ & “ & $0.41 \pm 0.015$ & $0.019 \pm 0.003$ & $0.68 \pm 0.21$ \\
\hline $07-8$ & $39.009520,43.486980$ & “ & $0.45 \pm 0.015$ & $0.013 \pm 0.002$ & $0.43 \pm 0.15$ \\
\hline 07-33 & $39.000590,43.472950$ & Trachybasalt & $1.17 \pm 0.02$ & $0.034 \pm 0.003$ & $0.42 \pm 0.06$ \\
\hline $07-100$ & $39.118960,43.430600$ & “ & $1.22 \pm 0.02$ & $0.031 \pm 0.003$ & $0.36 \pm 0.06$ \\
\hline \multicolumn{6}{|c|}{ Stream of the Bendimahi River Valley (Tendurek Volcano) } \\
\hline $07-48$ & $39.051420,43.761010$ & Tephrite & $1.43 \pm 0.02$ & $0.029 \pm 0.003$ & $0.29 \pm 0.05$ \\
\hline
\end{tabular}

Note: The ground mass of the rock was analyzed. The coordinates of the sample locations are shown in the WGS- 84 system.

lites are unconformably overlain by the marine clastic sediments which are Paleogene in age and then in turn by the Miocene limestones and continental Early Pliocene sediments higher in the sequence. Based on geological data, the effusive rock sequences of the Aladag Volcanic Complex (Miocene) are considered to be the earliest of the Neogene-Quaternary volcanic rocks in the region in question; based on our observations, pillow lava horizons are typical of these effusive rock sequences. Thus, the majority of the North Van region was probably below the sea level located in a sea basin up until the Late Miocene, and the first eruptions of young lavas there could occur in subaqueous conditions.

The total amount of published geochronological data for young volcanites of the northern coast of Lake Van is extremely limited [3-5]. In the late 1970s, complex geological-geochemical investigations in the region in question were carried out by a group of Italian experts headed by Innocenti, who obtained a number of $\mathrm{K}-\mathrm{Ar}$ dates that allowed making preliminary conclusions on the time of the occurrence of collision magmatism in the Northern Van region [3, 4].

A detailed isotope-geochronological study of the area of young magmatism on the northern coast of Lake Van was performed in order to determine the principal time characteristics of volcanic activity in this region, namely its total duration, the start and termination time of major eruptions, and to identify the nature of the volcanism (discrete/continuous) and its principal stages and phases. In all, 45 new $\mathrm{K}-\mathrm{Ar}$ dates were obtained for Neogene-Quaternary volcanites in the region in question. The sample locations are shown in the geological map (see figure), and the dating results are provided in the table. The principal characteristics of the technique used for $\mathrm{K}-\mathrm{Ar}$ dating of young volcanic rocks are set forth in [6].

The oldest lavas dated by the authors come from the base of Aladag Volcanic Complex. These lavas are widespread in the northern and northeastern parts of the region studied (see figure). The age of these lavas (15.0-13.5 Ma) corresponds to the Serravalian, which is in line with the conclusion previously made by Innocenti and his colleagues $[3,4]$ that the magmatic activity north of Lake Van started in the Middle Miocene. Two other $\mathrm{K}-\mathrm{Ar}$ dates for lavas of the Aladag Volcanic Complex that fall within the abovementioned time span were obtained by the authors from andesite samples collected from the southwestern slope of the Tendürek Volcano, a few tens of kilometers northeast of the study area.

The stratigraphic position of the Middle Miocene lavas with the basement units is quite clearly seen in the valleys of the Zilan, Ilica, and Deliçay Rivers (see figure), where these lavas overlie Burdigalian limestones and marls that are exposed in fensters. The 15.0-13.5 Ma old andesites of the Aladag Volcanic Complex are overlain in many places by pyroclastic units having possibly the same age, and also by younger effusives. Thus, our isotope data clearly indicates that the collision-related volcanic activity initiated during the Serravalian period $(\sim 15 \mathrm{Ma})$ in the region on the northern coast of Lake Van, as a discrete 
stage (i.e. the First or Initial Stage) during the Middle Miocene.

After an extended period of magmatic inactivity in the region that probably lasted for at least $3 \mathrm{~m}$.y., the next stage of volcanism started at the beginning of the Late Miocene ( $10 \mathrm{Ma})$. Late Miocene effusives (the second sequence of the Aladag Volcanic Complex) have a widely varying chemical composition from basalts and occasional trachybasalts (hawaiites) to dacites. They widely crop out within a narrow eastwest extending belt nearly between the Ilica and Deliçay Rivers (see figure), where these effusives overlie Middle Miocene volcanites of the first sequence of the Aladag Volcanic Complex. Our geochronological data presented in this paper suggest that the Second Stage of the volcanism started $\sim 10$ Ma during the Late Miocene and lasted $\sim 9$ Ma spanning an activity period of around 1 myr. Note that the Late Miocene volcanic units erupted during the Second between $\sim 10$ and $\sim 9 \mathrm{Ma}$ are overlain and masked by the Quaternary lavas of the Girekol Volcano within a vast area.

The distribution of the known exposures of the Middle and Late Miocene volcanic units on the northern coast of Lake Van and in adjacent areas indicates that these rocks, which are the earliest of the Neogene-Quaternary magmatic rocks (15-9 Ma), are widespread there within quite a long (over $200 \mathrm{~km}$ ) NW-SE trending zone that starts near the town of Eleșkirt and ends in the area of the Iranian-Turkish border, south of theTendürek Volcano. The previously published isotope data obtained from the northern part of collision-related volcanic sequence range between 12 and $10 \mathrm{Ma}[5,7]$. On the basis of our own and literature data it can be assumed that the Middle and Late Miocene Stages of Late Cenozoic magmatism are diachronous i.e., they begin and end at different times in different areas within this zone. Our geochronologic data suggest that the earliest impulse of volcanic activity ( $15 \mathrm{Ma})$ most likely occurred in the southeastern sector of this zone.

After a long inactivity period lasted $\sim 3$ m.y., the collision-related volcanism in the region restarted around the end of Messinian (i.e.Latest Miocene) at $\sim 5.8 \mathrm{Ma}$. This third major volcanic period continued around 2 m.y. until it diminished at $\sim 3.7 \mathrm{Ma}$ in the Lower Pliocene (i.e. Zanclean). Its first impulse was apparently associated with the formation of thick volcanic succession consisting of trachytic ignimbrites, trachyandesitic lavas (i.e. benmoreites) and associated tuffs that cover a vast area in the northwest town of Erciş. These rocks are observed mainly around northwesternmost part of the study area, near the confluence of the Zilan and Ilica rivers. The $\mathrm{K}-\mathrm{Ar}$ dates of three samples (two ignimbrites and a tuff sample) from the Third Volcanic Stage span a relatively narrow range from 5.8 to $5.3 \mathrm{Ma}$. This is in good agreement with the results of previous studies by F. Innocenti and his colleagues $[3,4]$, who sampled these rocks along the val- leys of the Zilan River and its right tributaries and dated them as 5.9-4.7 Ma.

After a relatively short period of volcanic inactivity that lasted for a few hundred thousand years, magmatic activity in the region resumed with eruption of basaltic lavas (i.e. basalts and hawaiites) associated with rare mugearites and latites along the fissures. The alkalinity of the Pliocene basic lavas with age 4.94.6 Ma increased to the north. Rocks of that age are widespread within the entire area in question (see figure); the authors also examined these rocks on the eastern coast of Lake Van, where a basalt cover overlies the upper terraces of the paleovalley of the Bendimahi River directly on the Mesozoic-Early Cenozoic basement rocks. North of the Etrüsk Volcano, Early Pliocene trachybasalts form a vast plateau between the eastern slope of the Aladag Ridge and the western spurs of the Tendürek Volcano, where intermediate to basic lavas overlie either older Middle Miocene volcanites or Neogene sedimentary rock sequences, and to the north, Paleozoic metamorphic rock complexes.

The last phase of Pliocene magmatic activity on the northern coast of Lake Van was associated with eruptive activity of the large Etrüsk Volcano; the products of which are represented by trachytes, trachydacites, latites and rhyolites. Based on our data, the period of activity of this volcano comprises a time span between 4.3 and 3.7 Ma. Initial stage of this volcano was dominated by the eruption of lavas. Flows of trachyte-trachydacites spread in all directions from the top, but predominantly westwards, following the inclination of the paleovalley of the Bendimahi River. The present day frontline of trachytic lava flows which came from the summit of Etrüsk Volcano is observed near the town of Ercis, 20-25 km away from the eruption center, where they are overlain by younger effusives across a vast area. The remnants of these trachydacitic lavas are cropped out as small sporadic outcrops on the eastern coast of Lake Van. They are exposed there along the lower terraces of the paleovalley of the Bendimahi River, stratigraphically below the Early Pliocene basalts. During the Middle Pliocene, when Lake Van did not exist yet, lava flows from the Etrüsk Volcano moved down to the south following the paleovalley of the Bendimahi River, and partly filled it. Then, the river started cutting a new valley which is located to the north of its previous position.

The termination of eruptions of the Etrüsk Volcano was marked by the formation of a small (up to $5 \mathrm{~km}$ in diameter) collapse caldera, which was apparently accompanied by an explosive activity. This is confirmed by the presence of pyroclastic deposits observed by the authors on the slopes of the volcanic edifice, which overly the early lavas. Intrusion of a number of dykes and subvolcanic bodies with trachytic, trachydacitic and rhyolitic composition observed on the walls of the caldera structure probably coincided with the aforementioned caldera collapse stage. The final impulse of activity from the Etrüsk 
volcano was marked by the eruption of a thick and viscous rhyolitic lava flow from a flank eruption center on the southeastern flank $(\sim 3.8-3.7 \mathrm{Ma})$.

During the Late Pliocene ( 2.5 Ma [5]), after the formation of the Bitlis basanites which created a damlike topographical height in the south of the Nemrut Volcano, the Van Lake Depression was started to be filled with the waters of nearby river drainages. Our geochronological data indicate that there was no intense volcanic activity around the Northern Lake Van province up until the Middle Quaternary. The total duration of that period of inactivity was $\sim 3$ m.y.

Quaternary volcanism on the northern coast of Lake Van started $\sim 1 \mathrm{Ma}$ (see table). Its first impulse was probably not very intense: the authors identified only two lava flows of that age, which are represented by low potassium basalts. One of these lava flows erupted from Mt. Ormuk north of the Girekol Volcano, while the second one probably erupted from an approximately $\mathrm{N}-\mathrm{S}$ extending fissure cutting the western slope of the Etrüsk Volcano.

Our geochronological data suggest that the second phase of Quaternary volcanism $(\sim 600 \mathrm{ka})$ in the Northern Lake Van area was marked by the eruptions from fissures and small cones located on these fissures. Low potassium basalts reached to the surface along these fissures. One of these volcanoes was located some $10-12 \mathrm{~km}$ north from the mouth of the Deliçay River; its lavas spread primarily southwards and thereafter were overlain with effusives of the Girekol Volcano within a vast area (see figure). Another volcanic edifice which was active at the same period of time was located west of the Etrüsk Volcano. After the eruption of lavas that moved southwards and reached Lake Van (see figure), the Geyik Çukuru crater up to $700 \mathrm{~m}$ in diameter formed in its place. Another fissure eruption occurred around $600 \mathrm{ka}$ is located in the vicinity of the Çolpan village on the eastern coast of Lake Van. The bottom surface of those basaltic lavas is almost on the same level with the present-day lake surface. The trachyandesitic-basaltic lava flows exposed around the upper course of the Ilica River and the watershed of the Aladag Ridge possibly erupted around $600 \mathrm{ka}$, too. Note that the average weighted value of the $\mathrm{K}-\mathrm{Ar}$ age for volcanic rocks of the second phase of Quaternary magmatic activity (based on five dates) is $0.60 \pm$ $0.02 \mathrm{Ma}$.

Finally, young volcanism on the northern coast of Lake Van was terminated $\sim 400 \mathrm{ka}$. The formation of the Girekol Volcano that erupted basaltic and hawaiitic lavas with a distinct mera-porphyric texture (with the appearance of coarse plagioclase phenocrysts reaching in length to over a centimeter) and that of Karniyrik cinder cone located to the southeast of Mt. Girelol (see figure) falls within this period as well. The products erupted from the Karniyrik cinder cone are hawaiitic in composition. Another but much smaller and isolated eruption center during the same period was discovered by the authors on the coast of
Lake Van, located southwest of the Karniyarik Volcano. The average weighted value of the $\mathrm{K}-\mathrm{Ar}$ age of the lavas of that impulse of magmatism is $0.39 \pm 0.04 \mathrm{Ma}$.

The youngest lava flow dated in this study is a $0.3-$ 0.2 Ma-old tephrite, exposed along the base of the Bendimahi River valley. This lava flow can be followed all the way along the Bendimahi River valley between the towns of Muradiye and Çaldiran. The eruptive center of this tephrite flow is located on the Çaldiran plain. We ague that the Bendimahi River tephrite should be associated with the Tendürek Volcanic system, rather than that of the Northern Van Neovolcanic province as it was generated from somewhere around the south of Tendürek volcano. Therefore, although this lava flow is in direct contact with the Etrüsk lavas, it is unlikely that it has any genetic connection with the Northern Van Neovolcanic system. Thus, the magmatic activity in the area of the northern end of Lake Van stopped no later than $0.4 \mathrm{Ma}$; because no younger occurrences have been observed by the authors in the region.

Taking all the above into consideration, some principal conclusions can be made on the evolution of the Neogene-Quaternary volcanism in the Northern Van Neovolcanic Province. The total duration of magmatic activity in the region was $\sim 15 \mathrm{Ma}$; it had an expressed discrete nature, when periods of intense volcanic activity alternated with lasting breaks in eruptions. Four stages of Neogene-Quaternary volcanism were identified by the authors: Middle Miocene (15.0-13.5 Ma, andesites), Late Miocene (10-9 Ma, basalts and dacites), Pliocene (5.8-3.7 Ma, basalts, hawaiites, mugaerites, latites, trachydacite-trachytes, and rhyolites), and Quaternary (1.0-0.4 Ma, basalts, hawaiites and mugaerites). The average duration of the stages was apparently 1-2 m.y.; the stages were separated from each other with periods of inactivity of approximately equal length ( $\sim 3$ m.y.). For each of the Pliocene and Quaternary stages, three additional phases of volcanism were identified by the authors; these additional phases were separated from each other with short time intervals (a few hundred thousand years). The last burst of volcanic activity in the area in question took place $\sim 400 \mathrm{ka}$; similar to Quaternary volcanism in general, it was not characterized by high intensity or considerable volumes of erupted material. The discrete nature of magmatism in the region could be caused to some extent by geotectonic reasons, namely sequential strengthening/weakening of convergence processes between the Eurasian and Arabian lithosphere plates in different parts of the collision zone, and possibly by impulsive motion of the slab or lithosphere mantle after the break off and delamination of the slab in the asthenosphere beneath the region in question [1, etc.]. Volcanism of the two initial stages was generally characterized by the prevalence of rocks of calc-alkaline series [3, 4]. For the Pliocene and Quaternary stages, the early phases were marked by predominant eruptions of normal alkalinity 
basalts, and the concluding phases were characterized by eruptions of moderately alkaline lavas (trachytetrachydacites in the Pliocene and trachybasalts in the Anthropogene).

A very important result of the studies performed was to confirm the existence of a separate Middle Miocene stage of collision volcanism in the Caucasian-Anatolian Segment of the Alpine Fold Belt. Previously, the authors also obtained some evidence of the occurrence of magmatism of that age in the Lesser Caucasus (Guria, Georgia); however, the range of activity there was apparently extremely insignificant at that time [8]. The data generated allow the conclusion that Neogene-Quaternary volcanism in this portion of the Alpine Fold Belt started much earlier ( 15 Ma) than assumed by the majority of previous researchers.

\section{ACKNOWLEDGMENTS}

This work was supported by a joint project of the Russian Foundation for Basic Research, grant no. 0905-91220-ST, and the Scientific and Technological Research Council of Turkey, grant no. 108Y222. We acknowledge the support of the Research Foundations of Istanbul University, project no. ACIP-1282, and the Van Yüzüncü Yil University, project no. 2008-FBED137, which enabled us to perform fieldwork in Eastern Anatolia in 2007 and 2008, respectively.

\section{REFERENCES}

1. M. Keskin, Geol. Soc. Am. 430, 693-722 (2007).

2. E. E. Milanovskii and N. V. Koronovskii, Orogeneous Volcanism and Tectonics of Alpian Belt in Eurasia (Nedra, Moscow, 1973) [in Russian].

3. F. Innocenti, R. Mazzuoli, G. Pasguare, et al., J. Volcanol. Geotherm. Res. 1, 103-112 (1976).

4. F. Innocenti, R. Mazzuoli, G. Pasguare, et al., Geol. Rundsch. 69, 292-323 (1980).

5. T. Ercan, T. Fujitani, J.-I. Madsuda, et al., Maden tetkin ve arama. Dergisi 110, 143-164 (1990).

6. I. V. Chernyshev, V. A. Lebedev, and M. M. Arakelyants, Petrologiya 14, 69-89 (2006) [Petrology 14, 62 (2006)].

7. M. Keskin, J. A. Pearce, and J. G. Mitchell, J. Volcanol. Geotherm. Res. 85, 355-404 (1998).

8. V. A. Lebedev, V. G. Sakhno, and A. I. Yakushev, Dokl. Akad. Nauk 426, 802-808 (2009) [Dokl. Earth Sci. 426, 819 (2009)]. 